JMPF Vol. 9 No. $3: 143-150$

ISSN-p : 2088-8139

ISSN-e : $2443-2946$

DOI : $10.22146 /$ jmpf.37624

\title{
Perkiraan Kadar Seftazidim dalam Darah pada Pasien Pneumonia dengan Gangguan Fungsi Ginjal
}

\author{
Estimated Blood Concentration of Ceftazidime in Pneumonia Patients with Renal Impairment
}

\author{
Dewi Latifatul IIma ${ }^{1 *}$, Djoko Wahyono², Ika Puspita Sari² \\ 1. Jurusan Farmasi, Fakultas IImu-IImu Kesehatan, Universitas Jenderal Soedirman, Purwokerto \\ 2. Fakultas Farmasi Universitas Gadjah Mada, Yogyakarta \\ Submitted: 7-29-2018 Revised: 2-7-2019 \\ Korespondensi : Dewi Latifatul IIma : Email : dewilatifatulilma@gmail.com \\ Accepted: 9-24-2019
}

\begin{abstract}
ABSTRAK
Pneumonia merupakan salah satu penyebab terbesar mortalitas karena infeksi terbesar pada pasien yang dirawat di rumah sakit dan sering dijumpai pada pasien dengan gagal ginjal. Luaran klinis pasien infeksi dengan gagal ginjal lebih buruk dibanding pasien tanpa gagal ginjal. Adanya gangguan ginjal berpengaruh terhadap farmakokinetika obat. Seftazidim merupakan salah satu antibiotik yang sering digunakan pada pasien pneumonia. Sekitar $80-90 \%$ fraksi obat utuh seftazidim dieliminasi oleh ginjal sehingga adanya gangguan pada ginjal akan berpengaruh terhadap kadar seftazidim dalam darah. Penelitian ini bertujuan untuk mengetahui estimasi kadar seftazidim dalam darah dan luaran klinis pasien pneumonia dengan gangguan ginjal. Penelitian ini adalah penelitian retrospektif dengan desain observasional deskriptif. Data diperoleh dari rekam medik pasien di salah satu rumah sakit di Yogyakarta pada periode antara Januari 2013-Juni 2017 yang memenuhi kriteria inklusi yaitu pasien berusia $\geq 18$ tahun dengan data rekam medik lengkap, dirawat di bangsal penyakit dalam dengan diagnosis pneumonia (HAP/HCAP) yang mengalami gangguan fungsi ginjal kronik, dan mendapat terapi seftazidim minimal 72 jam atau 3 hari. Jumlah sampel penelitian yang memenuhi kriteria inklusi sebanyak 40 pasien. Hasil peneltian menunjukkan bahwa terdapat 31 pasien (77,5\%) yang mencapai estimasi kadar seftazidim dalam darah di atas nilai minimum inhibitory concentration yaitu $8 \mu \mathrm{g} / \mathrm{mL}$. Setelah terapi seftazidim, 19 pasien $(47,5 \%)$ memiliki luaran klinis membaik dan 21 pasien $(52,5 \%)$ belum membaik.
\end{abstract}

Kata kunci: pneumonia; gangguan ginjal; seftazidim; estimasi kadar

\section{ABSTRACT}

Pneumonia is one of the major causes of mortality due to infection in hospitalized patients. It was frequently found in patients with renal failure. Clinical outcomes of infected patients with renal failure are worse compared to patients without renal failure. The presence of renal impairment affects the pharmacokinetics of the drug. Ceftazidime is one of the most commonly used antibiotics in patients with pneumonia. Approximately, $80-90 \%$ of ceftazidime's total drug fraction is eliminated by kidneys so that the presence of kidney disorders will affect the concentration of ceftazidime in the blood. This study aimed to determine the estimated concentration of ceftazidime in the blood and clinical outcome of pneumonia patients with renal impairment. This study was a retrospective study with descriptive observational design. Data were obtained from patient's medical record in a hospital in Yogyakarta between January 2013-June 2017 which fulfilled the inclusion criteria, i.e., $\geq 18$ years old patients with complete medical record data, treated in internal medicine ward with diagnosis of pneumonia (HAP/HCAP) who had chronic renal failure, and received ceftazidime for minimum 72 hours or 3 days. The number of research samples were 40 patients. This study showed that 31 patients $(77.5 \%)$ had achieved estimated ceftazidime concentration in the blood above the minimum inhibitory concentration of $8 \mu \mathrm{g} /$ $\mathrm{mL}$. After ceftazidime therapy, 19 patients (47.5\%) had improved clinical outcome and 21 patients (52.5\%) had not improved clinical outcome.

Keywords: pneumonia; renal impairment; ceftazidime; estimated concentration

\section{PENDAHULUAN}

Pneumonia, baik hospital-acquired pneumonia (HAP) atau healthcare- associated pneumonia (HCAP) merupakan penyebab terbesar morbiditas dan mortalitas karena infeksi di rumah sakit. Insidensi HAP mencapai 5 sampai lebih dari 20 kasus setiap 1000 pasien yang masuk rumah sakit, sedangkan HCAP ditemukan pada $20 \%$ kasus dari 4543 pasien yang dirawat di 
rumah sakit karena pneumonia dengan kematian akibat HAP dan HCAP berturutturut sebanyak 19,8\% dan 18,8\%1. Penelitian di Indonesia menunjukkan bahwa insidensi HAP sebesar 0,54\% dari 100.000 pasien yang dirawat di rumah sakit dengan kematian mencapai $0,082 \%$.

Pneumonia merupakan infeksi komorbid yang sering dijumpai pada pasien dengan gagal ginjal. Luaran klinis pasien yang menderita gagal ginjal dan infeksi lebih buruk dibandingkan dengan pasien tanpa gagal ginjal ${ }^{3,4}$. Selain berpengaruh terhadap luaran klinis pasien, proses farmakokinetika seperti distribusi obat (termasuk volume distribusi dan ikatan protein) dan eliminasi (termasuk biotransformasi dan ekskresi ginjal) dapat berubah karena gangguan ginjal ${ }^{5}$.

Seftazidim merupakan salah satu antibiotik golongan sefalosporin generasi ketiga yang sering digunakan pada pasien HAP/HCAP karena memiliki spektrum aktivitas luas dan dapat membunuh bakteri Gram negatif seperti Pseudomonas aeruginosa, Klebsiella pneumonia, dan Acinetobacter species. Bakteri-bakteri ini merupakan salah satu penyebab pneumonia ${ }^{6-8}$. Seftazidim dieliminasi terutama oleh ginjal dalam bentuk utuh sebesar $80-90 \%$ sehingga adanya gangguan pada ginjal akan berpengaruh terhadap kadar seftazidim dalam darah ${ }^{5,9}$. Kadar antibiotik harus dijaga berada pada kisar terapetiknya sehingga dapat bekerja secara optimal dalam membunuh bakteri. Selain terkait dengan efektivitas terapi, kadar yang optimal juga dapat mencegah terjadinya resistensi bakteri dan toksisitas ${ }^{10}$.

Penelitian terkait kadar seftazidim dalam darah pernah dilakukan oleh Izumikawa et al. (2009) yang mengevaluasi pemberian seftazidim dosis 1 gram q.i.d pada pasien HAP dan diperoleh hasil bahwa pemberian seftazidim 1 gram q.i,d dapat dipertimbangkan dalam meningkatkan efikasi seftazidim karena tingginya kadar seftazidim dalam darah pada periode yang lama ${ }^{11}$. Belum ada penelitian yang secara langsung mengevaluasi tentang kadar seftazidim dalam darah jika diberikan sesuai dengan dosis pasien di rumah sakit dan menghubungkannya dengan luaran klinis pasien pneumonia di Indonesia. Salah satu metode yang dapat digunakan untuk mengetahui kadar obat dalam darah adalah dengan melakukan perhitungan estimasi kadar obat menggunakan rumus farmakokinetika. Oleh karena itu, pada penelitian ini dilakukan perhitungan estimasi kadar seftazidim dalam darah dan dihubungkan dengan luaran klinis pasien pneumonia dengan gangguan ginjal untuk mengetahui efektivitas terapi seftazidim pada pasien.

\section{METODE}

Penelitian ini adalah penelitian retrospektif dengan desain observasional deskriptif. Pengumpulan data dilakukan menggunakan teknik purposive sampling dengan menganalisis data rekam medik pasien di salah satu rumah sakit di Yogyakarta periode Januari 2013-Juni 2017 yang memenuhi kriteria inklusi yaitu pasien berusia $\geq 18$ tahun dengan data rekam medik lengkap, dirawat di bangsal penyakit dalam dengan diagnosis pneumonia (HAP/HCAP) yang mengalami gangguan fungsi ginjal kronik, dan mendapat terapi seftazidim minimal 72 jam atau 3 hari.

Estimasi kadar seftazidim dalam darah pada keadaan tunak dihitung menggunakan rumus ${ }^{5}$.

$$
\begin{aligned}
& \mathrm{Css}^{\mathrm{maks}}=\frac{\mathrm{Div}}{\mathrm{Vd}}\left(\frac{1}{1-\mathrm{e}^{-\mathrm{k} \cdot \tau}}\right) \\
& \mathrm{Css}^{\mathrm{min}}=\mathrm{Css}^{\text {maks }} \cdot \mathrm{e}^{-\mathrm{k} \cdot \tau}
\end{aligned}
$$

Keterangan: Css $^{\text {maks }}=$ kadar maksimal obat dalam darah; $\mathrm{Css}^{\mathrm{min}}=$ kadar minimal obat dalam darah; Div = dosis intravena; $\mathrm{Vd}=$ volume distribusi; $\tau=$ interval pemberian obat; $\mathrm{K}=$ konstanta eliminasi obat.

Luaran klinis pasien dilihat dari hasil terapi antibiotik seftazidim untuk infeksi pneumonia (HAP/HCAP) yang ditandai dengan perubahan kondisi klinis pasien setelah diterapi dengan seftazidim. Kondisi klinik yang diamati meliputi suhu tubuh, 
Dewi Latifatul Ilma, et al

Tabel I. Karakteristik Demografi Pasien Pneumonia dengan Gangguan Ginjal

\begin{tabular}{lcc}
\hline \multicolumn{1}{c}{ Karakteristik } & Variasi Kelompok & Jumlah (\%) \\
\cline { 3 - 3 } Usia (tahun) & $18-<60$ & $\mathbf{N}=\mathbf{4 0}$ \\
\multirow{2}{*}{ Jenis Kelamin } & $\geq 60$ & $24(60)$ \\
\multirow{2}{*}{ Keadaan } & Laki-laki & $16(40)$ \\
& Perempuan & $24(60)$ \\
& Immunocompromised & $16(40)$ \\
& Non-Immunocompromised & $12(30)$ \\
\hline
\end{tabular}

detak jantung, jumlah leukosit, laju pernafasan, dan batuk. Pasien dikatakan membaik jika kondisi klinik pasien mengalami perbaikan atau terdapat pernyataan membaik dari dokter. Selain itu, dilihat juga hubungan antara estimasi kadar seftazidim dalam darah dengan luaran klinis menggunakan uji chi square.

\section{HASIL DAN PEMBAHASAN Gambaran Karakteristik Demografi dan Terapi Antibiotik Pasien}

Jumlah pasien pneumonia (HAP dan HCAP) dengan gangguan ginjal pada penelitian ini sebanyak 40 pasien (Tabel I), dengan 36 pasien $(90 \%)$ menderita HCAP dan 4 pasien $(10 \%)$ menderita HAP. Sebagian besar pasien berusia $18-<60$ tahun yaitu sebanyak 24 pasien $(60 \%)$. Hasil ini berbeda dengan penelitian lain yang menyatakan bahwa pneumonia baik HAP/HCAP lebih banyak diderita oleh pasien berusia lanjut karena faktor usia berpengaruh terhadap kerentanan seorang mengalami infeksi akibat perubahan fisiologi tubuh. Peningkatan usia terkait dengan penurunan sistem imun (seperti perubahan fungsi sel $\mathrm{B}$ dan sel $\mathrm{T}$, respon imun bawaan, serta efektor), perubahan fungsi perlindungan kulit dan mukosa, serta berkurangnya kapasitas pernafasan ${ }^{12}$. Ratarata usia pasien pada penelitian ini yaitu $55 \pm 15,9$ tahun. Penurunan fungsi timus yang berperan dalam pematangan sel $\mathrm{T}$ limfosit mencapai puncaknya pada usia 40-50 tahun ${ }^{13}$. Hal ini menjadi salah satu alasan lebih besarnya jumlah pasien dengan usia 18- $<60$ tahun pada penelitian ini, selain karena jumlah sampel yang sedikit.
Jenis kelamin yang mendominasi yaitu laki-laki sebanyak 24 pasien (60\%). Hasil ini sesuai dengan penelitian yang menyatakan bahwa penderita pneumonia didominasi oleh laki-laki sebanyak $65,14 \%$. Penelitian lain juga memberikan hasil yang serupa yaitu penderita HCAP didominasi oleh pria sebanyak 63,9\% dan 65,5\% untuk HCAP/HAP ${ }^{13,14,15}$. Faktor yang diduga berpengaruh terhadap tingginya kejadian pneumonia pada laki-laki adalah faktor gaya hidup seperti merokok yang lebih umum dilakukan oleh pria, meskipun prevalensi pada wanita juga semakin meningkat. Merokok merupakan faktor risiko terjadi infeksi pada saluran pernafasan karena merokok dapat merusak epitel saluran pernafasan. Epitel ini berfungsi untuk menghilangkan patogen yang dapat menyebabkan infeksi. Selain itu, faktor hormon juga mempengaruhi kejadian pneumonia dimana hormon testosteron pada laki-laki dapat memicu terjadinya immunosuppression yang mengurangi proliferasi sel $\mathrm{T}$ dan $\mathrm{B}$ serta produksi immunoglobulin dan sitokin setelah pubertas. Hormon estrogen pada wanita dapat meningkatkan sistem imun karena kemampuannya untuk meregulasi $\mathrm{CD}^{+}$sel $\mathrm{T}^{17}$.

Keadaan immunocompromised diderita oleh 12 pasien (30\%). Keadaan immunocompromised pasien yaitu kanker sebanyak 11 pasien dan penderita HIV (Human immunodeficiency virus) sebanyak 1 pasien. Pasien dengan keadaan immunocompromised tidak memiliki kemampuan normal untuk berespon terhadap 
Tabel II. Terapi Kombinasi Antibiotik pada Pasien Pneumonia dengan Gangguan Ginjal

\begin{tabular}{lcc}
\hline \multicolumn{1}{c}{ Antibiotik } & Jumlah Pasien & Persentase (\%) \\
\hline Seftazidim + Siprofloksasin & 27 & 67,5 \\
Seftazidim + Levofloksasin & 4 & 10 \\
Seftazidim + Azitromisin & 2 & 5 \\
Seftazidim + Gentamisin & 2 & 5 \\
Seftazidim + Siprofloksasin + Klindamisin $^{*}$ & 1 & 2,5 \\
Seftazidim + Siprofloksasin + Kotrimoksazol $^{*}$ & 1 & 2,5 \\
Seftazidim + Levofloksasin + Metronidazol* $^{*}$ & 1 & 2,5 \\
Seftazidim + Gentamisin + Metronidazol $^{*}$ & 1 & 2,5 \\
Seftazidim + Levofloksasin + OAT $^{*} \quad$ & 1 & 2,5 \\
\multicolumn{1}{c}{ Total } & 40 & 100 \\
\hline
\end{tabular}

Keterangan: *: antibiotik yang tidak tercantum dalam guideline ATS (2005) untuk terapi $\mathrm{HAP} / \mathrm{HCAP}$

infeksi karena melemahnya sistem imun. Pneumonia merupakan infeksi yang sering dialami oleh pasien dengan immunocompromised karena paru-paru merupakan jalan masuk bagi patogen dari udara. Keganasan merupakan faktor risiko berkembangnya pneumonia dan adanya kanker meningkatkan keparahan penyakit. Pasien kanker sering berkunjung ke rumah sakit untuk perawatan antikanker seperti terapi pembedahan, kemoterapi, dan radiasi. Hal ini diduga menyebabkan pasien kanker lebih mudah terpapar bakteri penyebab pneumonia $^{18}$.

Antibiotik utama yang digunakan pada penelitian ini adalah seftazidim dari golongan sefalosporin generasi ketiga. Seftazidim merupakan golongan antibiotik sefalosporin generasi ketiga yang memiliki spektrum yang luas melawan bakteri Gram positif dan negatif, termasuk $P$. aeruginosa. Sayangnya seiring berjalannya waktu, kemampuan sefalosforin untuk melawan infeksi yang terkait bakteri Gram negatif menjadi berkurang karena meningkatnya bakteri extended-spectrum $\beta$-lactamases (ESBLs), $K$. pneumonia, atau bakteri MDR lainnya ${ }^{19}$. Pemberian antibiotik pada pasien dengan HCAP/HAP harus diberikan secepat mungkin, karena terlambatnya pemberian antibiotik terkait dengan peningkatan morbiditas dan mortalitas ${ }^{1}$. Bakteri-bakteri yang biasanya menginfeksi pasien HAP adalah Enterobacteriaceae (misal Klebsiella spp., Enterobacter spp., dan Serratia spp.), S. aureus (termasuk MRSA), $P$. aeruginosa, atau $A$. baumannii. HCAP biasanya melibatkan bakteri seperti S. pneumonia, K. pneumonia, dan $S$. aureus ${ }^{1}$. Sedangkan menurut ATS6, HAP dan HCAP biasanya disebabkan oleh infeksi bakteri Gram negatif seperti P. aeruginosa, K. pneumoniae, dan Acinetobacter spp., atau oleh bakteri Gram positif seperti $S$. aureus atau MRSA.

Seluruh pasien menggunakan seftazidim dengan dikombinasi oleh antibiotik dari golongan lain. Peningkatan resistensi antibiotik terhadap penggunaan betalaktam tunggal, termasuk sefalosforin, mendorong timbulnya penggunaan antibiotik secara kombinasi. Kombinasi antibiotik yang paling banyak digunakan oleh pasien pada penelitian ini adalah kombinasi seftazidim dengan antibiotik golongan fluorokuinolon seperti siprofloksasin atau levofloksasin (Tabel II). Hal ini sesuai dengan penelitian yang menyatakan bahwa kombinasi yang paling sering $(48,6 \%)$ digunakan adalah beta laktam antipseudomonal dan fluorokuinolon ${ }^{20}$. Kombinasi lainnya adalah dengan makrolida yaitu azitromisin dan aminoglikosida yaitu gentamisin. Penggunaan kombinasi sefalosforin antipseudomonal (seftazidim) dan fluorokuinolon antipseudomonal (siprofloksasin atau levofloksasin) atau aminoglikosida (gentamisin) 
Dewi Latifatul Ilma, et al

Tabel III. Estimasi Kadar Seftazidim dalam Darah (Css ${ }^{\text {maks }}$ dan Css ${ }^{\min }$ ) Pasien Pneumonia dengan Gangguan Ginjal

\begin{tabular}{ccccc}
\hline Jumlah Pasien & Do RS & $\tau$ & Css $^{\text {maks }}(\mu \mathrm{g} / \mathbf{m L})$ & Css $^{\min }(\boldsymbol{\mu g} / \mathbf{m L})$ \\
\hline 2 & 500 & 12 & $54,93-92,13$ & $31,79-53,31$ \\
$15^{*}$ & 500 & 24 & $22,37-76,70$ & $7,49-25,68$ \\
5 & 500 & 48 & $21,73-44,69$ & $2,44-5,01$ \\
2 & 1000 & 8 & $233,72^{+}$ & $162,29^{+}$ \\
2 & 1000 & 12 & $111,1-148,69$ & $64,09-86,04$ \\
$13^{*}$ & 1000 & 24 & $44,28-162,7$ & $6,4-54,47$ \\
2 & 1000 & 48 & $78,87-89,38$ & $8,84-10,02$ \\
\hline
\end{tabular}

Keterangan: Do RS : Dosis seftazidim yang diberikan pada pasien (mg) di rumah sakit; Cssmaks: Nilai perkiran kadar maksimal seftazidim dalam darah $(\mu \mathrm{g} / \mathrm{mL})$; Css $^{\text {min }}:$ Nilai perkiraan kadar minimal seftazidim dalam darah $(\mu \mathrm{g} / \mathrm{mL})$; MIC: minimum inhibitory concentration $(\mu \mathrm{g} / \mathrm{mL})$; *: Satu pasien mendapat dua dosis yang diberikan bergantian yaitu $500 \mathrm{mg} / 24 \mathrm{jam}$ dan $1000 \mathrm{mg} / 24$ jam; ${ }^{+}$: Nilai Css ${ }^{\text {maks }}$ dan Css ${ }^{\text {min }}$ kedua pasien sama.

direkomendasikan untuk mengatasi HAP/HCAP karena infeksi bakteri MDR seperti P. aeruginosa, K. pneumoniae, atau Acinetobacter spp. Kombinasi antipseudomonal sefalosforin (seftazidim) dan makrolida (azitromisin) dipilih jika HAP/HCAP disebabkan oleh bakteri $L$. pneumophila, atau dapat juga menggunakan kombinasi antipseudomonal sefalosforin (seftazidim) dan fluorokuinolon antipseudomonal (siprofloksasin atau levofloksasin) ${ }^{6}$. L. pneumophila merupakan bakteri atipikal yang dapat menyebabkan infeksi pneumonia, tetapi bakteri ini jarang diidentifikasi pada praktek klinik.

\section{Estimasi Kadar Seftazidim dan Luaran Klinis Pasien}

Estimasi kadar seftazidim dihitung berdasarkan dosis yang diberikan oleh klinisi, dengan menggunakan parameter farmakokinetika yang berasal dari pustaka. Parameter farmakokinetika pustaka yang digunakan adalah $\mathrm{Vd}$ dan $\mathrm{t}_{1 / 2}$ eliminasi. Nilai kadar estimasi yang dihitung adalah nilai $\mathrm{Css}^{\text {maks }}$ dan $\mathrm{Css}^{\mathrm{min}}$. Nilai $\mathrm{Vd}$ mengacu pada nilai $\mathrm{Vd}$ seftazidim pasien dewasa dengan gangguan ginjal yaitu $0,28 \mathrm{~L} / \mathrm{kgBB}$ dan nilai $\mathrm{t}_{1 / 2}$ eliminasi tergantung dari nilai klirens kreatinin pasien yang dihitung berdasarkan rumus Cockcroft-Gault. Estimasi kadar yang diperoleh kemudian dibandingkan dengan nilai minimum inhibitory concentration (MIC) berdasarkan AST (Antimicrobial Susceptibility Testing) dari CLSI (Clinical and Laboratory Standard Institute) tahun 2016. Apabila estimasi nilai $\mathrm{Css}^{\mathrm{min}}$ antibiotik dibawah nilai MIC maka antibiotik tidak dapat menimbulkan efek terapi ${ }^{21}$. MIC merupakan salah satu prediktor utama untuk efikasi terapi antimikroba ${ }^{22}$. Nilai MIC yang digunakan adalah nilai MIC bakteri P.aeruginosa yaitu $8 \mu \mathrm{g} / \mathrm{mL}$.

Hasil perhitungan menunjukkan bahwa kadar maksimal seftazidim dalam darah (Css ${ }^{\text {maks})}$ yaitu 21,73-233,72 $\mu \mathrm{g} / \mathrm{ml}$ (median, $54,93 \mu \mathrm{g} / \mathrm{ml}$ ) dan kadar minimal seftazidim dalam darah $\left(\mathrm{Css}^{\mathrm{min}}\right)$ yaitu $2,44-162,29 \mu \mathrm{g} / \mathrm{ml}$ (median, 14,73 $\mu \mathrm{g} / \mathrm{ml}$ ). Dosis yang diberikan pada pasien bervariasi dengan rentang 500$1000 \mathrm{mg}$ dan interval 8-48 jam (Tabel III). Jika dibandingkan dengan nilai MIC bakteri P.aeruginosa, sebanyak 31 pasien $(77,5 \%)$ memiliki estimasi kadar seftazidim dalam darah di atas nilai minimum inhibitory concentration yaitu $8 \mu \mathrm{g} / \mathrm{mL}$ dan 9 pasien nilai estimasi kadar seftazidim dalam darahnya di bawah MIC. Luaran klinis pasien setelah terapi seftazidim menunjukkan bahwa 19 pasien (47,5\%) memiliki luaran klinis membaik dan 21 pasien $(52,5 \%)$ belum membaik. Selanjutnya dilakukan uji chi square untuk mengetahui 
Tabel IV. Analisis Hubungan Estimasi Kadar Seftazidim dengan Luaran Klinis menggunakan Uji Chi Square $(\mathrm{n}=40)$

\begin{tabular}{|c|c|c|c|c|}
\hline \multirow{3}{*}{ Estimasi kadar seftazidim } & \multicolumn{2}{|c|}{ Luaran Klinis } & \multirow{3}{*}{ Total N (\%) } & \multirow{3}{*}{$\mathbf{P}$} \\
\hline & Membaik & Belum membaik & & \\
\hline & N (\%) & N (\%) & & \\
\hline Di atas MIC & $15(37,5)$ & $16(40)$ & $31(77,5)$ & \multirow{2}{*}{0,835} \\
\hline Di bawah MIC & $4(10)$ & $5(12,5)$ & $9(22,5)$ & \\
\hline
\end{tabular}

hubungan antara estimasi kadar seftazidim dalam darah dengan luaran klinis pasien. Berdasarkan hasil analisis, diperoleh nilai $\mathrm{P}>0,05$ sehingga tidak ada hubungan yang signifikan antara estimasi kadar seftazidim dalam darah dengan luaran klinis pasien (Tabel IV). Meskipun penelitian lain menyatakan bahwa nilai MIC berpengaruh terhadap hasil terapi pasien, tetapi nilai MIC bukan satu-satunya yang dapat mempengaruhi efek terapi obat pasien. Faktor-faktor klinis lain yang dimiliki oleh pasien juga perlu dipertimbangkan ${ }^{22}$.

Berbagai faktor yang dapat berpengaruh terhadap hasil analisis pada penelitian ini, yaitu pasien-pasien pada penelitian tidak hanya diterapi oleh antibiotik seftazidim tetapi dikombinasi dengan antibiotik lain yang mana penggunaan antibiotik lain ini diduga juga berpengaruh terhadap luaran klinis pasien. Perlu diperhatikan juga bahwa untuk mencapai respon terapi yang adekuat maka antibiotik harus mencapai daerah tempat terjadinya infeksi, yaitu di paru-paru untuk infeksi pneumonia. Penetrasi antibiotik sefalosporin ke paru-paru bervariasi dari 30-100\%. Rasio kadar seftazidim di dalam darah dan ephitelial lining fluid (ELF) paru-paru sebesar 0.21 dengan probabilitas mencapai ELF rendah ${ }^{22,23}$. Selain itu, adanya penyakit penyerta infeksi lain yaitu sepsis dan syok sepsis diduga juga mempengaruhi luaran klinis pasien. Sepsis dan syok sepsis diderita oleh 17 pasien $(42,5 \%)$. Adanya sepsis diketahui dapat memperburuk luaran klinis pasien ${ }^{24}$.

Respon imun sepsis dikarakteristikkan bermula dari fase hiperinflamasi yang berubah menjadi fase imunosupresi dalam hitungan hari. Mediator proinflamasi yang terlibat meliputi tumor necrosis factor (TNF), interleukin-1 (IL-1), interleukin-6 (IL-6), dan chemokin. Ekspresi sitokin proinflamasi diregulasi melalui suatu mekanisme kompensasi oleh mediator antiinflamasi yaitu interleukin-10 (IL-10). Respon antiinflamasi ini penting untuk memperbaiki homeostatis imun setelah terjadinya stimulasi inflamasi pada infeksi. Tetapi, adanya reaksi antiinflamasi ini dapat menyebabkan terjadi imunosupresi yang mendeaktivasi leukosit sehingga meningkatkan kerentanan mengalami infeksi dan memicu kematian akibat ketidakmampuan tubuh untuk melawan infeksi ${ }^{25,26}$.

Adanya sepsis juga berpengaruh terhadap farmakokinetika antibiotik terutama yang bersifat hidrofilik seperti golongan betalaktam. Hal utama yang menyebabkan terjadinya perubahan farmakokinetik antibiotik pada pasien dengan sepsis adalah peningkatan volume distribusi, perubahan ikatan protein, kenaikan klirens ginjal, gangguan pada klirens ginjal, dan disfungsi hepar ${ }^{27}$. Selain faktor sepsis, gangguan ginjal juga berpengaruh terhadap farmakokinetika antibiotik. Adanya gangguan ginjal dapat memperlama antibiotik mencapai kadar tunak yang diharapkan, akibat meningkatnya volume distribusi dan meningkatnya waktu paruh eliminasi. Jika ingin mencapai kadar yang diharapkan dengan cepat, maka disarankan dengan pemberian loading dose pada pasien ${ }^{28}$. Estimasi kadar antibiotik dalam keadaan tunak diharapkan dapat memberikan gambaran Css ${ }^{\text {min }}$ atau Css ${ }^{\text {maks }}$ yang dapat dicapai berdasarkan dosis yang diberikan oleh klinisi. Tetapi, sebanyak 26 pasien pada penelitian ini melakukan hemodialisis ketika mendapat terapi seftazidim. Hemodialisis ini 
dapat mempersulit antibiotik yang dapat terdialisis untuk mencapai kondisi tunak. Seftazidim sendiri diketahui memiliki fraksi terdialisis yang cukup besar yaitu 50-100\% sehingga direkomendasikan memberikan dosis tambahan posdialisis. Menurut literatur, besarnya dosis tambahan posdialisis yang dapat diberikan yaitu $1 \mathrm{~g}^{29}$. Penelitian ini memiliki keterbatasan yaitu jumlah sampel penelitian yang kecil dan banyak variabel penelitian yang tidak terkendali.

\section{KESIMPULAN}

Sebanyak 31 pasien $(77,5 \%)$ memiliki estimasi kadar seftazidim dalam darah di atas nilai minimum inhibitory concentration yaitu 8 $\mu \mathrm{g} / \mathrm{mL}$ dan 9 pasien $(22,5 \%)$ estimasi kadar seftazidim dalam darahnya di bawah MIC. Setelah terapi seftazidim, 19 pasien $(47,5 \%)$ memiliki luaran klinis membaik dan 21 pasien $(52,5 \%)$ belum membaik.

\section{UCAPAN TERIMA KASIH}

Terima kasih saya ucapkan kepada Beasiswa Unggulan Kementerian Pendidikan dan Kebudayaan RI atas bantuan dana yang diberikan.

\section{DAFTAR PUSTAKA}

1. Montravers P, Harpan A, Guivarch E. Current and Future Considerations for the Treatment of Hospital-Acquired Pneumonia. Adv Ther. 2016;33(2):151166.

2. Azmi S, Mohamed S, Maimaiti N, et al. International Journal of Infectious Diseases Assessing the burden of pneumonia using administrative data from Malaysia, Indonesia, and the Philippines. Int J Infect Dis. 2016;49:8793.

3. Wang HE, Gamboa C, Warnock DG, Muntner P. Chronic Kidney Disease and Risk of Death from Infection. Am J Nephrol. 2011;34(4):330-336.

4. Su G, Xu H, Marrone G, Lindholm B, Wen Z, Liu X. Chronic kidney disease is associated with poorer in-hospital outcomes in patients hospitalized with infections: Electronic record analysis from China. Sci Rep. 2017;7(1):1-10.

5. Shargel, L. dan Yu AB. Shargel \& Yu's Apllied Biopharmaceutics and Pharmacokinetics. 7th Ed. New York: Mc Graw Hill Education; 2016.

6. ATS. Guidelines for the Management of Adults with Hospital-acquired, Ventilator-associated, and Healthcareassociated Pneumonia. Am J Respir Crit Care Med. 2005;171(4):388-416.

7. Grayson M., Mc Carthy J., Mills J, Mouton J., Norby S. Kucers' The Use of Antibiotics: A Clinical Review of Antibacterial, Antifungal, Antiparasit, and Antiviral Drugs. Vol 1. Sixth. Boca Raton: CRC Press; 2010.

8. Kalil AC, Metersky ML, Klompas M, et al. Management of Adults With Hospital-acquired and Ventilatorassociated Pneumonia: 2016 Clinical Practice Guidelines by the Infectious Diseases Society of America and the American Thoracic Society. 2016:1-51.

9. APhA. Drug Information Handbook: A Comprehensive Resources for All Clinicians and Healtchare Professionals. 26th ed. Lexi-Comp Inc; 2017.

10. Kumar A, Khrime D, Bansal N, Pandey AN, Varma A. Evaluation of Antibiotic Dose Adjustment in Patients with Renal Insufficiency in a Tertiary Care Center. Int J Contemp Med Res. 2016;550(5):13831385.

11. Izumukawa K, Hashiguchi K, Sawai T, et al. Study on the blood concentration and clinical efficacy of ceftazidim, a cephem antibiotic at a dose of one gram q.i.d for adult hospital-acquired pneumonia patients. Jpn J Antibiot. 2009;62(1):9-16.

12. Beckett CL, Harbarth S, Huttner B. Special considerations of antibiotic prescription in the geriatric population. Clin Microbiol Infect. 2015;21(1):3-9.

13. Weiskopf D, Weinberger B, Grubeckloebenstein B. The aging of the immune system. Transpl Int. 2009;22(11):10411050 . 
14. Caceres F, Welch VL, Kett DH, et al. Absence of Gender-Based Differences in Outcome of Patients with HospitalAcquired Pneumonia. J Women's Heal. 2013;22(12):1069-1075.

15. Seong GM, Kim M, Ph D, et al. Healthcare-Associated Pneumonia among Hospitalized Patients: Is It Different from Community Acquired Pneumonia? Tuberc Respir Dis (Seoul). 2014;76(2):66-74.

16. Tadros M, Williams V, Coleman BL, et al. Epidemiology and Outcome of Pneumonia Caused by MethicillinResistant Staphylococcus aureus ( MRSA ) in Canadian Hospitals. PLoS One. 2013;8(9):4-11.

17. Silveyra P, Fuentes N, Rivera L. Understanding The Intersection of Environmental Pollution, Pneumonia, and Inflammation : Does Gender Play A Role? In: Contemporary Topics of Pneumonia. London: Intech; 2017.

18. Rabello LSCF, Silva JRL, Azevedo LCP, Souza I, Viviane B. Clinical Outcomes and Microbiological Characteristics of Severe Pneumonia in Cancer Patients : A Prospective Cohort Study. PLoS One. 2015;10(3):1-13.

19. Lagacé-wiens P, Walkty A, Karlowsky JA. Ceftazidime - avibactam: an evidence-based review of its pharmacology and potential use in the treatment of Gram-negative bacterial infections. Core Evid. 2014;9:13-25.

20. Seong GM, Kim M, Lee J, et al. Healthcare-Associated Pneumonia among Hospitalized Patients: Is It Different from Community Acquired Pneumonia? Tuberc Respir Dis (Seoul). 2014;76(2):66-74.

21. Hakim L. Farmakokinetika Klinik.
Yogyakarta: Bursa Ilmu; 2012.

22. Sharma R, Sapkota S, Khanal D. Correlation of Minimum Inhibitory Concentration of Ciprofloxacin to the Therapeutic Response of Patient With Urinary Tract Infection Caused by Escherichia Coli. IJPSR. 2014;5(3):970976.

23. Jamal J, Hons B, Hons B, Lipman J, Roberts JA, Hons B. Defining Antibiotic Dosing in Lung Infections. Clin Pul Med. 2013;20(3):121-128.

24. Mayr FB, Yende S, Angus DC. Epidemiology of severe sepsis. Virulence. 2014;5(1):4-11.

25. Sundar KM, Sires M. Sepsis induced immunosuppression: Implications for secondary infections and complications. Indian J Crit Care Med. 2013;17(3):162169.

26. Hotchkiss RS. Sepsis-induced immunosuppression: from cellular dysfunctions to immunotherapy. Nat Rev Immunol. 2014;13(12):862-874.

27. Blot SI, Pea F, Lipman J. The effect of pathophysiology on pharmacokinetics in the critically ill patient - Concepts appraised by the example of antimicrobial agents. Adv Drug Deliv Rev. 2014;77:3-11.

28. Verbeeck RK, Musuamba FT. Pharmacokinetics and dosage adjustment in patients with renal dysfunction. Eur J Clin Pharmacol. 2009;65(8):757-773.

29. Loo AS, Neely M, Anderson EJ, Ghossein C, McLaughlin MM, Scheetz MH. Pharmacodynamic Target Attainment for Various Ceftazidime Dosing Schemes in High-Flux Hemodialysis. Antimicrob Agents Chemother. 2013;57(12):5854-5859. 